NBER WORKING PAPER SERIES

\title{
INDICATOR PROPERTIES OF THE \\ PAPER-BILL SPREAD: LESSONS \\ FROM RECENT EXPERIENCE
}

Benjamin M. Friedman

Kenneth N. Kuttner

Working Paper No. 4969

\section{NATIONAL BUREAU OF ECONOMIC RESEARCH 1050 Massachusetts Avenue \\ Cambridge, MA 02138 \\ December 1994}

This paper is part of NBER's research program in Monetary Economics. Any opinions expressed are those of the authors and not those of the National Bureau of Economic Research.

(C) 1994 by Benjamin M. Friedman and Kenneth N. Kuttner. All rights reserved. Short sections of text, not to exceed two paragraphs, may be quoted without explicit permission provided that full credit, including () notice, is given to the source. 


\title{
INDICATOR PROPERTIES OF THE
}

PAPER-BILL SPREAD: LESSONS

FROM RECENT EXPERIENCE

\begin{abstract}
A feature of U.S. post-war business cycle experience that is by now widely documented is the tendency of the spread between the respective interest rates on commercial paper and Treasury bills to widen shortly before the onset of recessions. By contrast, the paper-bill spread did not anticipate the 1990-91 recession.

Empirical work presented in this paper supports two (not mutually exclusive) explanations for this departure from past experience. First, at least part of the paper-bill spread's predictive content with respect to business cycle fluctuations stems from its role as an indicator of monetary policy, but the 1990-91 recession was unusual in post-war U.S. experience in not being immediately precipitated by tight monetary policy. Second, movements of the spread during the few years just prior to the $1990-91$ recession were strongly influenced by changes in the relative quantities of commercial paper, bank CDs and Treasury bills that occurred for reasons unrelated to the business cycle.
\end{abstract}

This latter finding in particular sheds light on the important role of imperfect substitutability of different short-term debt instruments in investors portfolios, and highlights the burdens associated with using relative interest rate relationships as business cycle indicators.

Benjamin M. Friedman Department of Economics Harvard University Littauer Center 127 Cambridge, MA 02138 and NBER
Kenneth N. Kuttner

Federal Reserve Bank of Chicago 230 LaSalle Street Chicago, IL 60604-1413 
Revised

November, 1994

\section{INDICATOR PROPERTIES OF THE PAPER-BILL SPREAD: \\ LESSONS FROM RECENT EXPERIENCE}

Benjamin M. Friedman and Kenneth N. Kuttner*

Numerous researchers writing in recent years have documented the information content, with respect to subsequent fluctuations in U.S. real output, of the difference between the respective interest rates on commercial paper and Treasury bills. ${ }^{1}$ As Figure 1 shows, the paper-bill spread tends to widen markedly about six months before the onset of a business recession. Since 1959 the spread has averaged 88 basis points during all six-month periods immediately prior to recessions and 103 basis points during recessions, versus only 39 basis points in all other months. ${ }^{2}$ Various researchers have shown that this relationship has historically been highly significant in standard regression analysis (more or less regardless of what other regressors the equation includes), in Granger-type "causality" tests, and in variance decompositions based on vector autoregressions. By-now familiar reasons why the paper-bill spread would widen in anticipation of business downturns include the possibility that a widening spread is (a) an indicator of tight monetary policy, (b) a reflection of anticipations of business bankruptcies, and (c) a result of corporations' growing cash requirements as the business expansion nears its peak. $^{3}$

By contrast, the paper-bill spread completely failed to anticipate the 1990-91 recession. As Figure 2 shows in more detail, the spread fluctuated at 
Figure 1

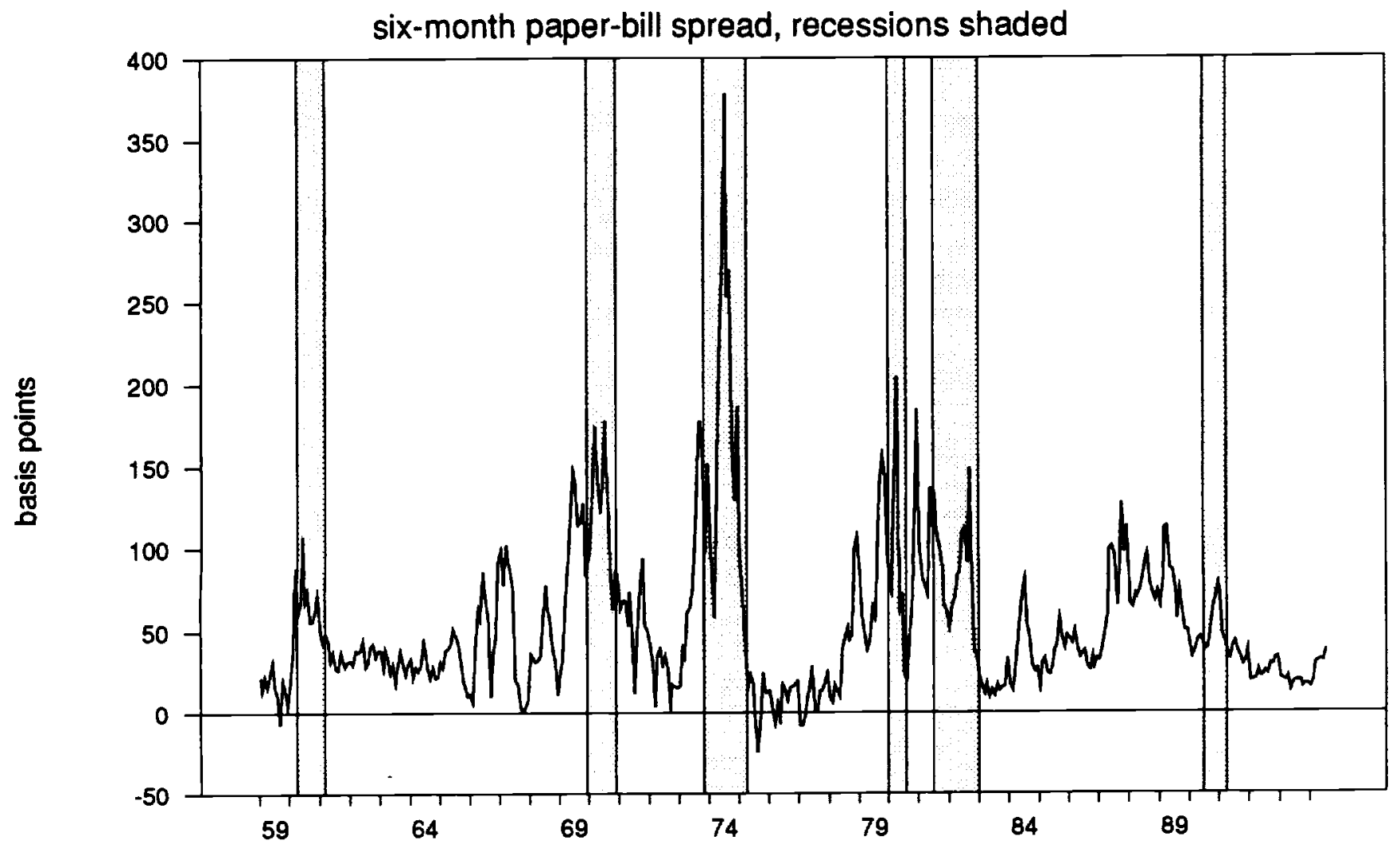

Figure 2

six-month paper-bill spread, 1986-94

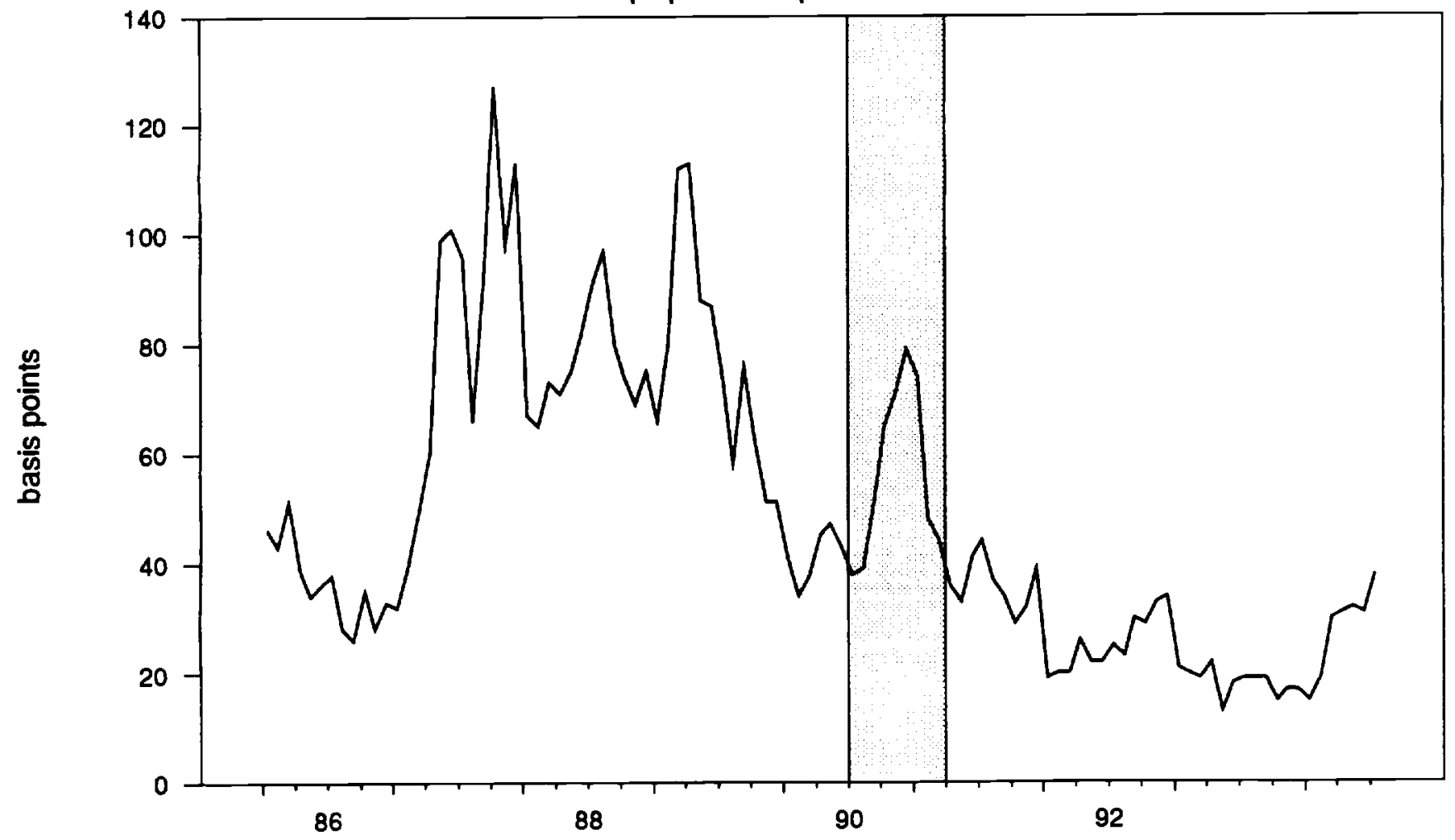


levels normally predictive of recession from mid 1987 to mid 1989, then narrowed sufficiently to eliminate any indication of recession by the beginning of 1990 , and did not noticeably begin to widen again until after the recession had begun in July 1990. Since then the behavior of the paper-bill spread has been more consistent with prior patterns. The spread declined sharply just as the recession ended in March 1991, and from then through mid 1994 (the time of writing) It remained at narrow, clearly non-recessionary levels.

The failure of the paper-bill spread to anticipate the $1990-91$ recession was a failure shared by essentially all familiar monetary and financial indicator variables. For example, growth of the M2 money stock peaked in late 1986 and by yearend 1987 had slowed to rates that historically would have predicted recession. Growth of M2 revived in 1988, faltered again in early 1989, but then revived even more strongly from mid 1989 onward so that by the time the recession began, at midyear 1990, M2 also was giving just the opposite signal. The slope of the yield curve, another familiar business cycle indicator, flattened in 1988 and throughout 1989 in a way that often anticipates recessions, but by early 1990 the yield curve began to steepen again while the recession was still a half a year away. Some researchers have concluded, in part on the basis of this universal failure of standard indicator variables drawn from the financial side of the economy, that the 1990-91 recession was unique in its origins. ${ }^{4}$

The object of this paper is to see what conclusions can be drawn from a closer look at the failure of the paper-bill spread in particular during this episode. To anticipate, the results of this analysis offer some support for the claim that the 1990-91 recession was highly unusual in post World War II U.S. experience, at least in not being immediately precipitated by tight monetary policy. In addition, however, the results point also to developments in both 
fiscal policy and debt management policy during the late 1980 s as a potential explanation. Pursuing this particular line of analysis clarifies the key role of imperfect substitutability of commerical paper and Treasury bills in investors' portfolios, and highlights the burdens that such imperfect substitutability places on the use of this or any similar interest rate spread variable as a business cycle indicator. 


\section{Potential Explanations for the Failure}

Why might the paper-bill spread have so completely failed to anticipate the 1990-91 business recession? At least three different explanations are plausible.

Absence of tight monetary policy. First, if fluctuations of the paper-bill spread mostly indicate changes in the stance of monetary policy, but tight monetary policy did not play a significant role in bringing about the 1990-91 recession, there is no reason why the spread should have widened in advance of this decline in output. Several researchers writing on this subject have worked out models in which a widening paper-bill spread is an indicator of tight monetary policy. ${ }^{5}$ In brief, the central idea is that restricting the growth of bank reserves causes banks to be less forthcoming in granting loans, which in turn drives would-be borrowers to seek funds in the commercial paper market instead. All other things equal, the resulting increase in commercial paper issuance would then raise the paper rate, relative to the Treasury bill rate, either because the marginal borrowers driven out of the banking system are on average smaller and less creditworthy than borrowers already active in the commercial paper market (so that the average liquidity and quality of outstanding paper deterforate) or simply because investors regard paper and bills as imperfect portfolio substitutes (so that relative outstanding quantitites affect relative required returns). 6

Although the subject remains one of contention, many economists have documented the key role of tight monetary policy -- however defined and measured - in bringing about most if not all U.S. business downturns. ${ }^{7}$ To the extent that that is so, and that tight monetary policy also widens the paper-bill spread, movements in the spread would naturally contain systematic information about subsequent movements in real output. But in the case of a decline in 
output that occurred independently of tight money -- for example, because of an adverse supply shock, or tight fiscal policy, or a fall in consumer confidence -. no such relationship would appear.

Idiosyncratic changes in asset quantities. Second, to the extent that commercial paper and Treasury bills are imperfect substitutes in investors' portfolios, so that changes in the relative outstanding supplies of these two instruments effect changes in their relative expected returns, those relative interest rate movements will be connected to business cycle fluctuations only if the underlying movements in the relative quantities are themselves a consequence of business cycle developments. Investors in U.S. markets plausibly treat commercial paper and Treasury bills as imperfect substitutes for several reasons, including differing state-level income tax treatment of interest earned (interest from bills is exempt), different liquidity (much greater for bills), and different default risk (zero for bills). ${ }^{8}$ Bank certificates of deposit are comparable to commercial paper on each of these criteria, and so it is also plausible to suppose that investors treat CDs as (nearly) perfect substitutes for paper, but imperfectly substitutable for bills. ${ }^{9}$ All other things equal, therefore, when factors related to the business cycle move the quantity of commercial paper and/or CDs -- for example, when tight monetary policy drives borrowers out of the banking system, or when slowing sales require firms to raise more cash to finance their inventories -- the resulting movements in the paper-bill spread bear a systematic relationship to movements in real output. By contrast, factors unrelated to the business cycle can also cause the relative quantitites of commercial paper, CDs and Treasury bills to vary, and these changes too imply movements in relative interest rates. For example, the Treasury's debt management policy determines the reliance on bills (that is, discounted obligations maturing in one year or less) versus longer-term 
coupon-bearing securities in financing a given U.S. Government deficit. State and local governments buy Treasury securities to "pre-refund" their own outstanding obligations, thereby reducing the market supply available to private investors. Foreign central banks that intervene to support the dollar exchange rate are free in principle to hold the dollars they acquire in any form they choose, but in fact the proceeds of such intervention go almost entirely into Treasury bills, again reducing the market supply available to private investors. The repeated finding that the paper-bill spread bears a highly significant relationship to business cycle fluctuations presumably means that "noise" in the spread due to such idiosyncratic movements in relative asset quantitites is mostly small compared to movements that are systematically connected to the business cycle. But it is also possible that a large enough idiosyncratic movement may dominate the movement of the paper-bill spread over any given period.

Increasing substitutability. Finally, it is also possible that the evolution of the U.S. financial markets over time has rendered commercial paper and Treasury bills more nearly perfect substitutes, perhaps to the point that the spread between these two instruments' respective returns no longer bears any systematic relationship to variations in their respective quantitites (or, for that matter, to anything else connected to the business cycle). ${ }^{10}$ The more the markets are dominated by tax-exempt institutional investors, the less important is the differential tax treatment of paper and bills. As the commercial paper market has grown over the years $(\$ 554$ billion in outstandings as of yearend 1993), the liquidity of the typical issue may have improved. And with but few actual defaults, at least among prime-rated issuers (and most issuers today backing up their outstanding commercial paper with lines of credit at banks), investors' perception of the default risk on commercial paper may have 
diminished. 11

One immediate implication of closer substitutability between commercial paper and Treasury bills would be a narrower average spread between their two respective interest rates. As Figures 1 and 2 illustrate, there is no evidence that such systematic narrowing occurred in the period leading up to the 1990-91 recession. (By contrast, part of the puzzle to be explained is that the spread was so wide from mid 1987 to mid 1989.) A further implication, however, is that the spread between returns on two assets that are increasingly close substitutes would exhibit fluctuations that were increasingly just random noise, rather than systematic reflections of anything connected to the business cycle. 


\section{A More Systematic Look at the Recent Experience}

Figure 3 shows the monthly movements, beginning in 1985, of the paper-bill spread together with three financial variables chosen to correspond to the three main hypotheses that researchers have suggested to account for the usual systematic relationship between the spread and real output: the federal funds rate, taken as an indicator of monetary policy; ${ }^{12}$ the interest rate differential between commercial paper issues rated P2 (the second-highest category) and PI (the highest) by Moody's Investors Service, taken as a measure of perceived default risk; and the quantity of outstanding commercial paper plus bank CDs, divided by this sum plus the quantity of outstanding Treasury bills, to measure relative asset quantities. ${ }^{13,14}$ In each panel of the figure, the solid line plots the variable's actual movement, while the broken line plots the corresponding movement attributable to the variable's "own" innovations as estimated from a six-variable vector autoregression including industrial production, the producer price index, these three financial indicators and the paper-bill spread itself, othogonalized in that order. The vector autoregression is estimated using monthly data for 1976:1-1994:5, with four lags on each variable.

Several relevant conclusions emerge from this comparison of actual fluctuations to the corresponding innovations. First, part of the "perverse" movement in the paper-bill spread during 1987-90 -- but importantly, for purposes of this paper's analysis, only part -. Is left as unexplained in the sense of being attributed to the spread's "own" innovations. From the low point in September 1986 to the high point in October 1987 (the month of the stock market crash), the spread widened by 101 basis points. The corresponding movement contributed by the spread's "own" innovations was just 47 basis points (with much of that occurring in the month of the crash), and by January 1988 the 

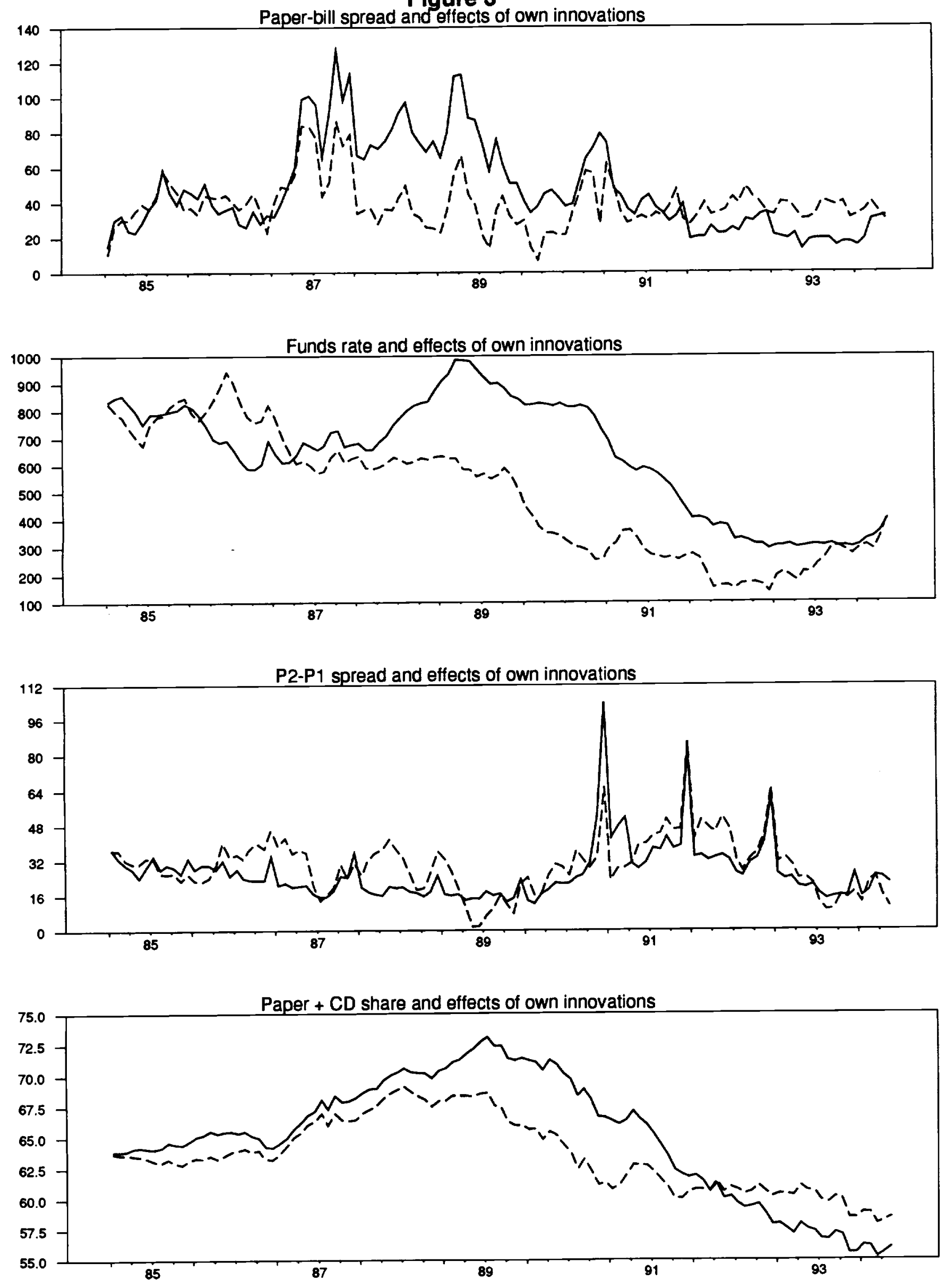
"own" component was already back to where it had been in September 1986. Similarly, the spread narrowed by 79 basis points between April 1989 and February 1990, but the corresponding movement in the "own" component was just (minus) 43 basis points. In other words, only a part of the movement in the spread during this period that ran so counter to prior business cycle experience was unexplainable noise. The rest can be attributed to systematic influences, including the three other financial variables represented in this system.

Which ones? Not monetary policy, or at least not according to this analysis. The (nominal) federal funds rate was low in 1987 when the spread was puzzlingly wide, and the funds rate was higher in 1989 when the spread was narrowing. The corresponding innovations in the federal funds rate tell qualitatively the same story, but here the main message is that quantitatively monetary policy was simply not very active. In contrast to the familiar finding of large positive funds rate innovations during the 1979-81 episodes of tight money under Paul Volcker, the "own" component of the funds rate changed little during the several years leading up to July 1990, and what change took place was mostly downward. This perspective on the more recent experience provides support for the familiar claim that the 1990-91 recession was unusual in not being proximately due to tight monetary policy. 15

Changes in perceived default risk also appear to have played a limited role here. Apart from a small but regular spike each December, presumably reflecting "window dressing" sales by institutions eager to show only top-rated paper on their year-end balance sheets, the P2-P1 quality differential followed a smooth, slightly downward trend from the middle 1980 s until just a few months before the 1990-91 recession began. The component of the quality differential attributable to that variable's "own" innovations showed somewhat closer correspondence with movements in the paper-bill spread -- especially the narrowing in mid 1987 and 
again in early 1989 -. but even here the correspondence is hardly close.

By contrast, the ratio of commercial paper and CDs to paper plus CDs plus Treasury bills fluctuated widely during this period, and especially during 1987-90 much of that fluctuation was attributable to this ratio's "own" innovations rather than the other variables included in this analysis. The sustained increase in the quantity ratio during 1986-89 (a period when many U.S. businesses were greatly increasing their debt loads through leveraged buy-outs, stock repurchases and debt-financed acquisitions) was in large part the cumulated effect of positive innovations, while a substantial part of the even more rapid decline of the quantity ratio during 1990-93 (the era of widespread "de-leveraging") was the cumulated effect of negative innovations. At least qualitatively, the bulge in the quantity ratio during 1987-88 would have caused the paper-bill interest rate spread to widen, and the decline in the quantity ratio from mid 1989 on would have caused the paper-bill spread to narrow. Moreover, to the extent that these movements in the quantity ratio were the effect of this variable's "own" innovations, not explained by the other variables in the system -. importantly including real output and prices .. the resulting quantity-driven influences on the spread would have been unrelated to the business cycle.

Figure 4 shows that these qualitative conclusions carry over to quantitative analysis. In each panel the solid line is the actual movement of the paper-bill spread during 1985:1-1994:5, and the dashed line is a corresponding "baseline" forecast generated by simulating forward the six-variable vector autoregression using data through the end of 1984 only. (These two lines are identical across all three panels in the figure.) The dotted line in each panel then shows the contribution to the paper-bill spread, measured around that baseline, of the estimated innovations corresponding to 
Figure 4
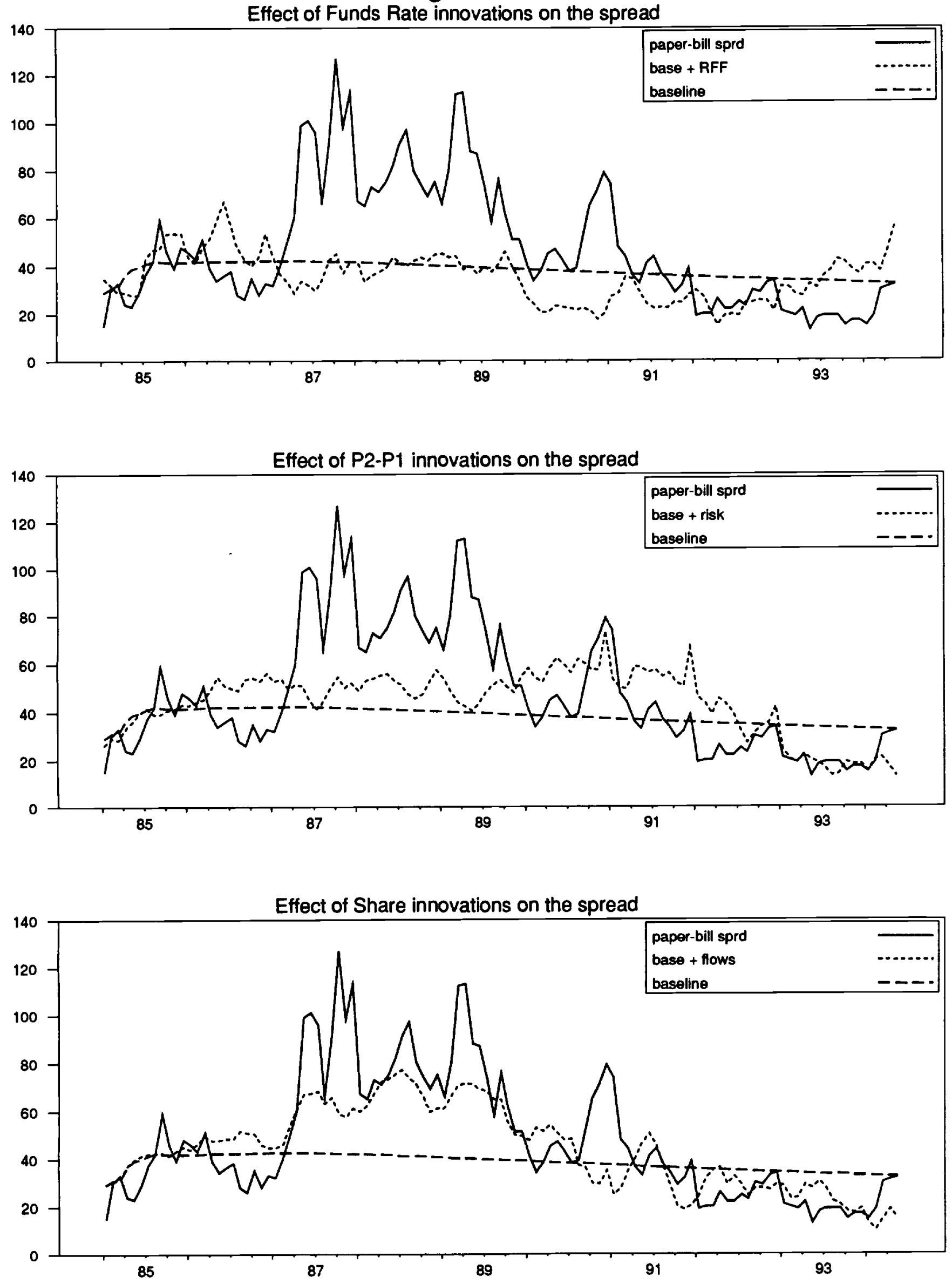
each in turn among the three other financial variables under study here.

Not surprisingly, the federal funds rate innovations played little if any role in accounting for the movement of the paper-bill spread during 1987-90. Unlike in the Volcker period, monetary policy seems not to have been much of a factor in this more recent episode. ${ }^{16}$ Default risk innovations likewise played little part. By contrast, much of the wide spread during 1987-88 and the narrowing of the spread in 1989 and early 1990 is attributable to quantity ratio innovations. Indeed, for the period January 1987 through June 1990 (the last month before the recession began) the simple correlation between the actual spread and the value calculated as the baseline plus the effect of quantity ratio innovations is .70 . The cumulative contribution to the spread due to quantity ratio innovations rose rapidly from just 4 basis points in January 1987 to 28 basis points in July, fluctuated around that level throughout the next two years (the peak effect was 37 basis points in July 1988), and then declined abruptly back to 9 basis points in January 1990. As Figure 5 shows, based on the identical vector autoregression simulated forward beginning in 1976, this large and sustained positive influence on the spread due to quantity ratio innovations during 1987-89 was highly unusual in historical context. 


\section{Figure 5}

Effect of Share innovations on the spread, 1976-1994

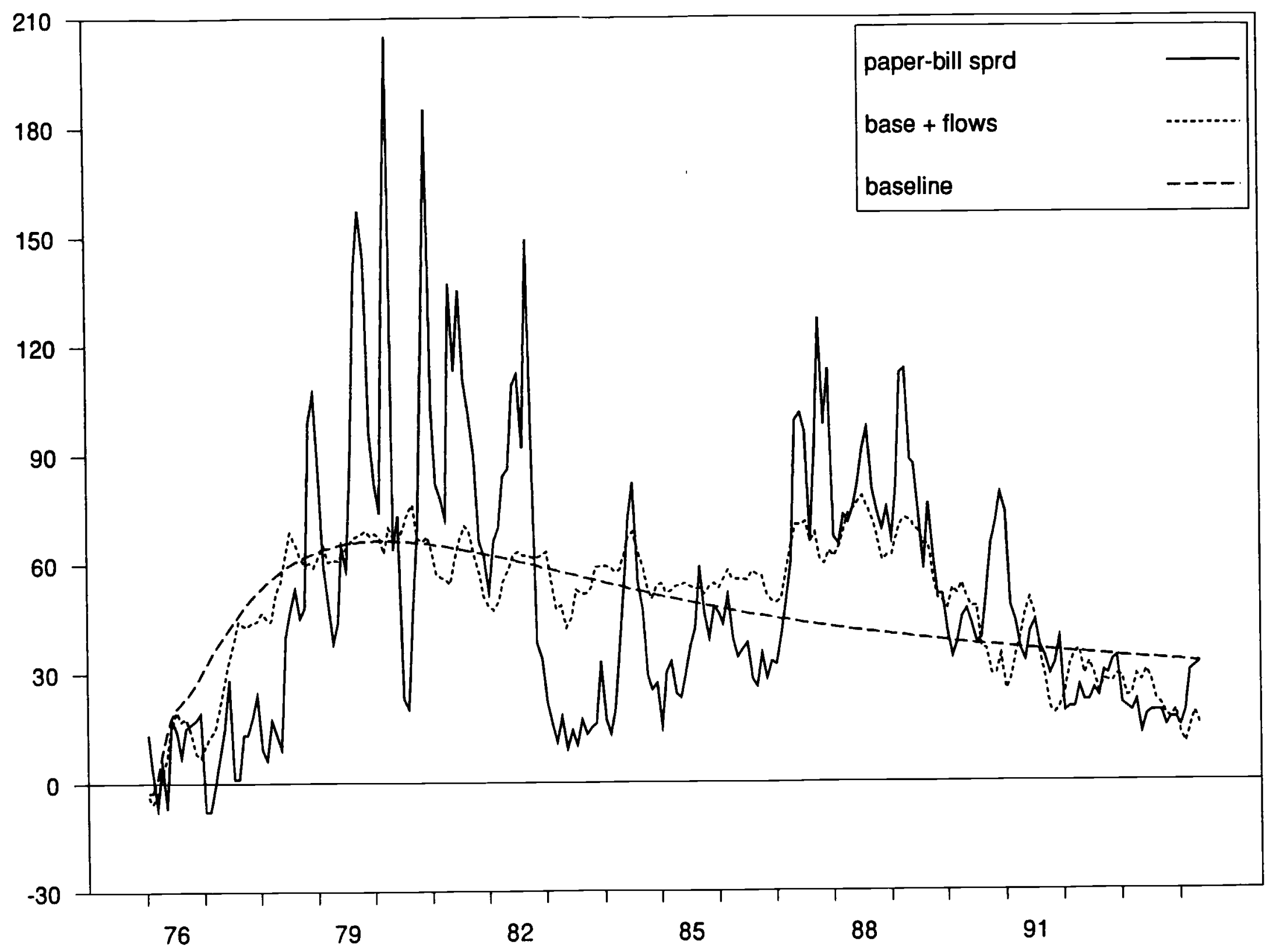




\section{Relative Quantity Movements and Their Effects}

Why did the quantity of commercial paper and bank CDs grow so rapidly compared to the quantity of Treasury bills from early 1987 through mid 1989 , only to go into reverse from then on? As Figure 3 shows (see again the bottom panel), much of the movement of this quantity ratio throughout 1987-90 represented historically large innovations, not explainable by fluctuations in real output and prices, or in any of the other financial variables under study here. What happened?

Figure 6 shows that each of the three assets that make up this ratio -. commercial paper, bank CDs and Treasury bills .. exhibited historically unusual movements during this period. Moreover, these respective movements reinforced one another so as to produce the quantity ratio's rapid rise from 1987 through mid 1989 and even more rapid decline thereafter (see again the bottom panel of Figure 3). Aggregate net issuance of commercial paper was especially large during 1988 and the first half of 1989 , then slowed until about the end of the recession in early 1991, and then ceased altogether for the next two years. Net issuance of bank CDs was likewise strong from 1987 through mid 1989, but then became negative not just through the recession but for the next two years as well. These developments presumably reflected some combination of the 1980 s corporate leverage movement and its aftermath, weakened capital positions of many commercial banks, and the more aggressive posture of bank regulators -. all of which by now are familiar stories -. in addition, of course, to the influence of the business cycle itself. 17

By contrast, net issuance of Treasury bills was approximately zero on average from yearend 1986 through mid 1989 -- just when issuance of commercial paper and bank CDs was so strong -. and then became unusually large just as issuance of paper and $C D$ s turned negative. As Table 1 shows, this pattern of 
Figure 6

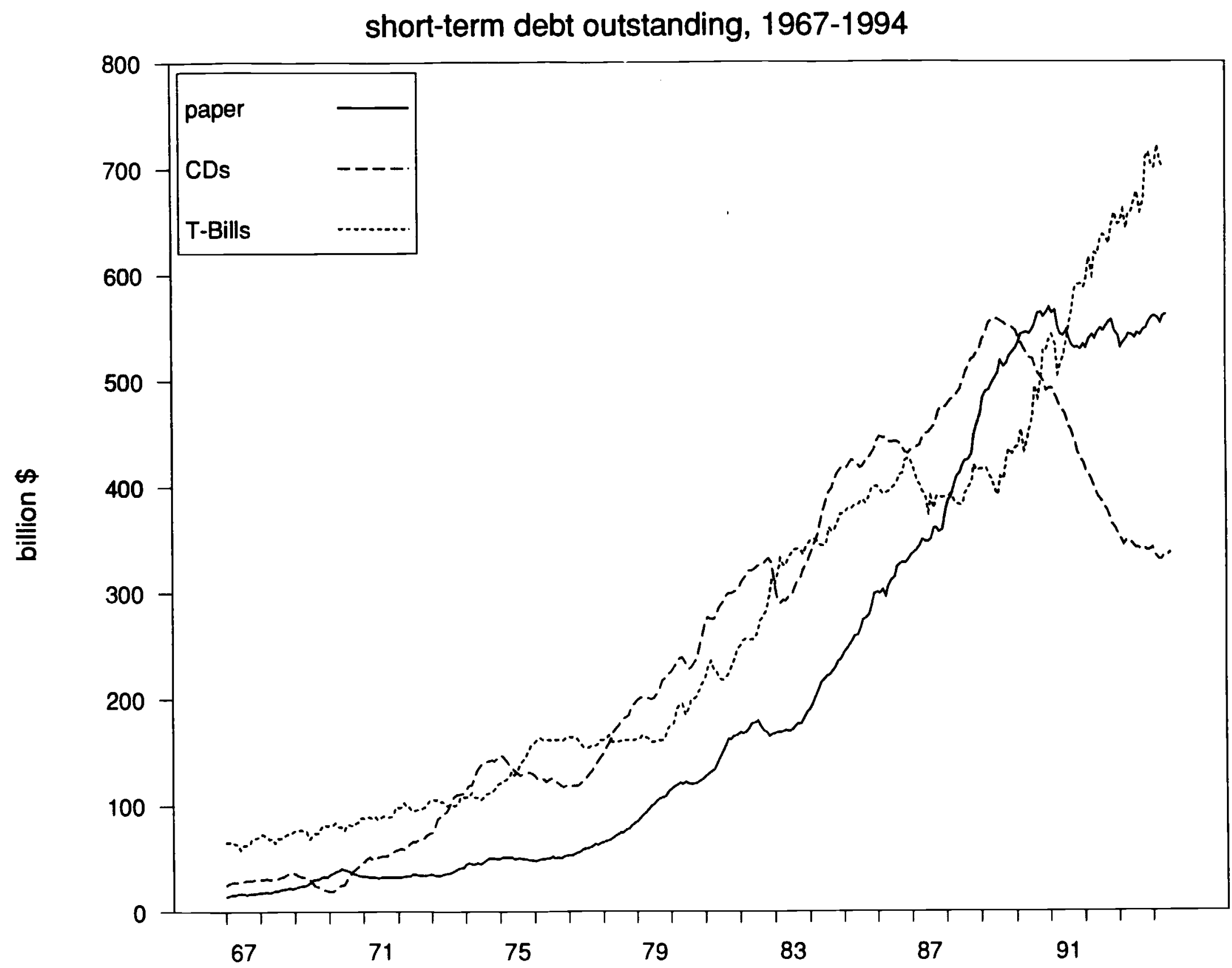




\section{Table 1}

Federal Deficit, Debt Structure, and Foreign Holdings of Bills

\begin{tabular}{cccccc}
\hline Year & $\begin{array}{c}\text { Federal } \\
\text { deficit }\end{array}$ & Bills & Notes & Bonds & $\begin{array}{c}\text { Foreign- } \\
\text { owned } \\
\text { Bills }\end{array}$ \\
\hline 1984 & 185.4 & 374.4 & 705.1 & 167.94 & 122.1 \\
1985 & 212.3 & 399.9 & 812.5 & 211.07 & 125.6 \\
1986 & 221.2 & 426.7 & 927.5 & 249.82 & 162.4 \\
1987 & 149.8 & 389.5 & 1037.9 & 282.48 & 198.3 \\
1988 & 155.2 & 414.0 & 1083.6 & 308.87 & 234.7 \\
1989 & 153.5 & 430.6 & 1151.5 & 348.21 & 233.0 \\
1990 & 220.5 & 527.4 & 1265.2 & 388.17 & 247.5 \\
\hline
\end{tabular}

Notes: Amounts shown are in billions of current dollars. Foreign-owned bills are those held in custody by the Federal Reserve Banks for foreign official and international accounts, as reported in the Federal Reserve's release H4.1. All figures are for December of the designated year, except those for the Federal deficit, which apply to the October 1 -September 30 fiscal year. 
bill issuance reflected a combination of fiscal policy, debt management policy and exchange rate policy (again together with the business cycle). The U.S. Government's budget deficit narrowed from $\$ 221$ billion in the 1986 fiscal year to $\$ 150$ billion in fiscal 1987 , and then remained at about that level for the next two years before widening to $\$ 221$ billion in 1990 (and $\$ 270$ billion in 1991). The Treasury chose to maintain approximately its normal schedule of offerings of notes and bonds throughout this period, however, and so the quantity of bills outstanding first shrank and then expanded. A typical weekly auction of bills in 1986 featured $\$ 15.0$ billion of new 13-and 26-week bills offered against $\$ 14.4$ billion of maturing bills. In 1987 the typical auction offered only $\$ 13.0$ billion of new bills against $\$ 13.5$ billion maturing. By fiscal 1990 the typical auction was up to $\$ 16.0$ billion of new bills against $\$ 13.8$ billion maturing. Further, just when net bill issuance was already negative, in 1987, foreign central banks were intervening in the exchange markets in support of the dollar, thereby increasing their bill holdings and correspondingly reducing the market supply. 18

Figure 7 highlights these developments by isolating the effect on the three-asset quantity ratio due to the respective movement in each of the three assets separately. The top panel of the figure shows how the actual movement of this ratio from 1987 on differed from an extrapolation of the modestly upward trend that had prevalled earlier on. The other three panels plot the cumulative effect on the ratio due to the deviation from the earlier (1985-86) trend of each in turn of the three asset quantities, keeping the other two to the earlier trend (so that the three cumulative effects plotted approximately add to the movement of the ratio itself, as shown in the top panel). The effect of all three assets - especially Treasury bills -- in increasing the quantity ratio during 1987, 1988 and early 1989 is clearly visible. So is the reversal of that 
Figure 7

Paper + CD share, actual and counterfactual
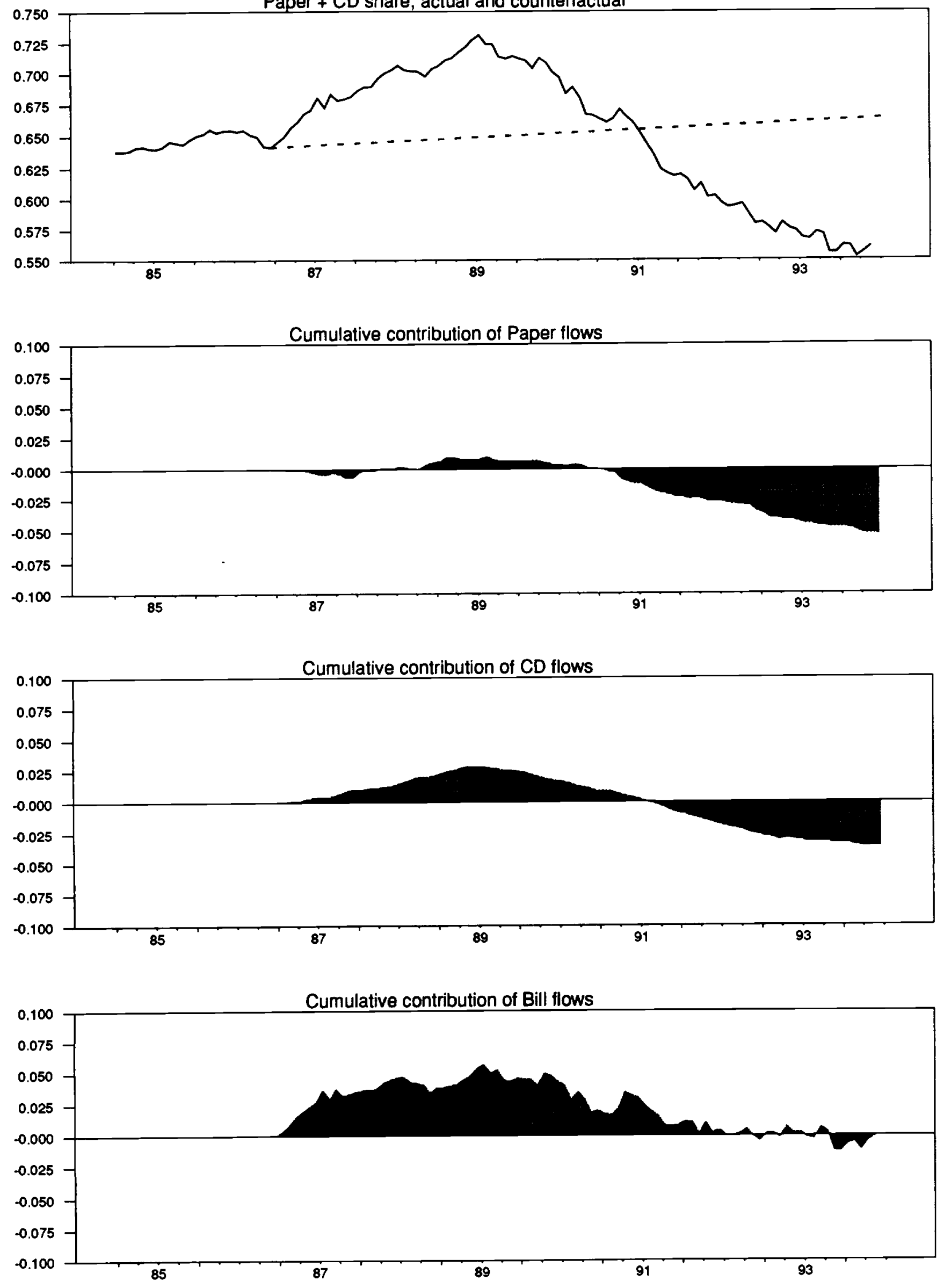
effect, for CDs and especially for commerical paper, from late 1989 on.

The vector autoregression simulation reported in Figure 3 already provides one estimate of the importance of these quantity effects in accounting for the historically atypical movement of the paper-bill spread during this period. Another follows from directly estimating the effect on the spread due to changing stock and flow quantities. Table 2 reports estimates, based on monthly data for 1975:1-1994:5, for the equation

$$
\begin{aligned}
\left(r_{p}-r_{B}\right)_{t}-\alpha+\beta & \frac{\Delta(P+C D)_{t}}{(P+C D+B)_{t-1}}+\gamma \frac{\Delta B_{t}}{(P+C D+B)_{t-1}} \\
& +\delta\left(\frac{P+C D}{P+C D+B}\right)_{t-1}+\theta\left(r_{P 2}-r_{P 1}\right)_{t}+\varphi t+u_{t}
\end{aligned}
$$

where the interest rate and asset quantity variables are defined in accordance with the previous discussion throughout this paper, and $u$ is a disturbance term. 19 The numbers shown in parentheses in the table are robust $t$-statistics corrected for twelfth-order moving-average serial correlation.

The first equation reported, estimated by ordinary least squares, shows that both flow and stock changes in asset quantities affect the paper-bill spread in the expected ways, and at high levels of statistical significance. An increase in the flow $\Delta(P+C D)$ by 18 per annum, relative to the outstanding stock $(P+C D+B)$, widens the paper-bill spread in the same month by between 1 and 2 basis points. An increase in the flow $\Delta B$ has an opposite (but smaller) effect. A permanent increase in the $(P+C D) /(P+C D+B)$ ratio widens the spread by almost 4 basis points. The equation also includes as a regressor the quality differential between P2- and P1-rated commercial paper, to allow for effects on the paper-bill spread due to changing perceptions of default risk, 


\section{Table 2}

Estimated Demand for Commercial Paper and CDs

Dependent variable $=$ six-month paper--bill spread

\begin{tabular}{lcc}
\hline \multirow{2}{*}{ Independent variable: } & \multicolumn{2}{c}{ Method: } \\
\cline { 2 - 3 } Paper + CD flow & OLS & TSLS \\
\hline Bill flow & 1.46 & 2.50 \\
& $(3.45)$ & $(5.09)$ \\
Lagged Paper + CD share & -0.44 & -0.37 \\
& $(2.47)$ & $(2.67)$ \\
P2-P1 spread & 3.72 & 3.14 \\
& $(6.04)$ & $(5.38)$ \\
Constant & 0.58 & 0.66 \\
& $(7.15)$ & $(7.91)$ \\
Trend & -2.25 & -2.06 \\
& $(6.30)$ & $(5.56)$ \\
Standard error & 0.0007 & 0.0014 \\
$\bar{R}^{2}$ & $(1.46)$ & $(2.67)$ \\
Durbin-Watson & 0.215 & 0.234 \\
& 0.67 & 0.61 \\
& 0.85 & 0.92 \\
\hline
\end{tabular}

Notes: The regressions are estimated on monthly data from 1975:1 through 1994:5. Both flow variables are annualized and normalized by the lagged stock of commercial paper + CDs + T-bills. The spread is expressed in percentage terms. Numbers in parentheses are robust standard errors, corrected for 12 th order moving-average serial correlation. In the TSLS regression, the flow of paper $+C D s$ is replaced by the instrument formed by its projection onto a constant, the lagged exogenous variables, and one lag of the ratio of non-borrowed to lagged total reserves. 
and this variable too is highly significant.

Issuance of bills is mostly a matter of Treasury policy, but issuance of both commercial paper and bank CDs is a market-determined outcome that plausibly depends on interest rate relationships. Table 2 therefore also reports the results of estimating equation (1) by two-stage least squares, where $\Delta(P+C D)$ is replaced by the instrument formed by the projection of $\Delta(P+C D)$ onto a constant, lagged values of all other regressors, and the lagged ratio of nonborrowed to total reserves (taken as a non-interest-rate measure of monetary policy). The resulting TSLS estimates are very similar to the OLS estimates shown immediately above, thereby providing further confidence that the estimated positive effect of paper and $C D$ issuance on the spread is not spurious.

Figure 8 shows the importance of these relative asset quantity effects for the paper-bill spread -- including during the 1987-90 period under study .- by plotting the actual spread together with the fitted values from the TSLS version of equation ( 1 ) and the corresponding values based only on the three quantity variables, the trend and the constant (that is, excluding the effect of the P2-P1 quality differential). Apart from the spike in the last quarter of 1987 , which was probably a reflection of the October stock market crash, the dotted line representing quantity effects alone does a good job of capturing the widening of the spread from 1987 through mid 1989 and the subsequent narrowing in late 1989 and early 1990. These direct estimates therefore reinforce the conclusion, based on the bottom panel of Figure 4, that the historically unusual movement of the paper-bill spread in the few years preceding the $1990-91$ recession was mostly due to idiosyncratic movements of the relevant asset quantities. 20 
Figure 8

Fitted effects of quantity movements on the spread

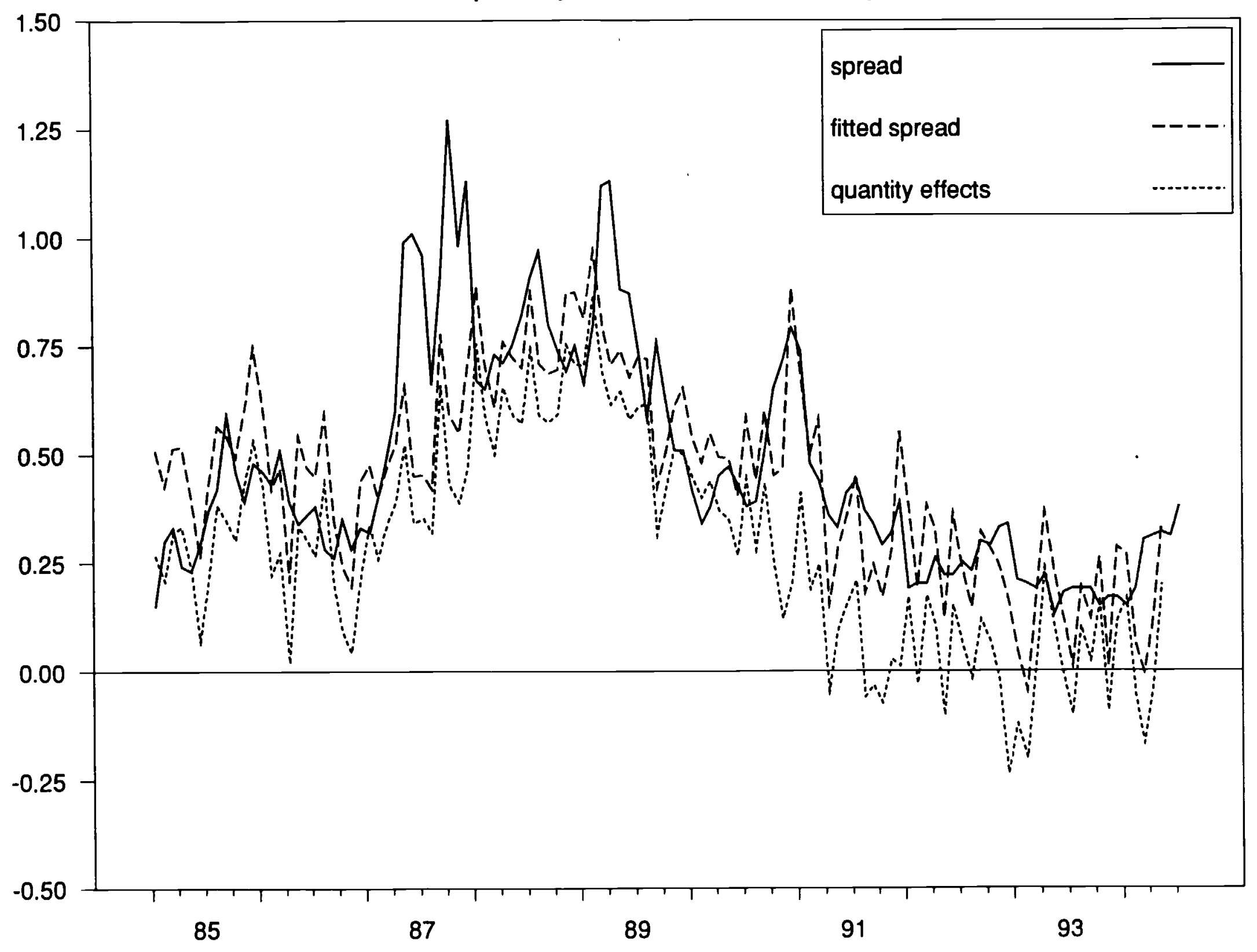


IV. Have Paper and Bills Become Closer Substitutes?

The focus on relative asset quantitles in the analysis reported in Section III makes sense only if commercial paper and Treasury bills are imperfect substitutes in investors' portfolios. When two or more assets are imperfect substitutes, standard portfolio theory indicates that changes in their relative quantities -. In other words, changes in their respective shares in the "market portfolio" - lead in general to changes in their relative market-clearing expected returns. By contrast, the expected returns on assets that are perfect substitutes are always identical (or, if there are non-pecuniary returns, they differ by a constant), regardless of their respective outstanding quantitites.

In contrast to the focus in Section III on relative quantity movements as the explanation for the paper-bill spread's failure to anticipate the 1990-91 recession, several researchers have suggested that movements in the spread have lost their predictive power over time as evolution of the U.S. financial markets has rendered commercial paper and Treasury bills if not perfect then at least much closer substitutes. 21 As Figure 1 shows, the average spread between the paper rate and the bill rate has not become systematically smaller in recent years. Even the fairly narrow average spread that prevailed after the 1990-91 recession ended was not atypical compared to prior non-recession periods. Evidence of increasing substitutability between paper and bills would therefore have to consist of a diminished relationship between the movements of the spread and the movements of the corresponding asset quantities.

The top panel of Table 3 reports estimates for an expanded version of equation ( 1 ) in which each in turn of the three flow and stock quantity variables is also entered multiplied by a zero-one dummy variable to admit a coefficient change as of the beginning of 1984 - that is, approximately at the mid-point of the sample. Evidence for increasing substitutability would be a 


\section{Table 3}

Tests for Parameteter Instability

Dependent variable $=$ six-month paper-bill spread

Using post-84 dummy variable

\begin{tabular}{lcccc}
\hline & \multicolumn{4}{c}{ Regression: } \\
\cline { 2 - 5 } Independent variable: & $(1)$ & $(2)$ & $(3)$ & $(4)$ \\
\hline Paper + CD flow & $1.64^{* * *}$ & $1.46^{* * *}$ & $1.44^{* * *}$ & $1.67^{* * *}$ \\
$\quad \times$ post-84 dummy & 0.64 & & & -0.69 \\
Bill flow & $-0.45^{* * *}$ & -0.41 & $-0.45^{* * *}$ & -0.41 \\
$\quad \times$ post-84 dummy & & 0.05 & & 0.09 \\
Lagged Paper + CD share & $3.87^{* * *}$ & $3.72^{* * *}$ & $3.89^{* * *}$ & $3.83^{* * *}$ \\
$\quad \times$ post-84 dummy & & & -0.10 & 0.03 \\
P2-P1 spread & $0.55^{* * *}$ & $0.58^{* * *}$ & $0.54^{* * *}$ & $0.56^{* * *}$ \\
Constant & $-2.32^{* * *}$ & $-2.25^{* * *}$ & $-2.34^{* * *}$ & $-2.31^{* * *}$ \\
Trend & 0.0007 & 0.0007 & 0.0010 & -0.0006 \\
Test for excluding dummies & & & & 1.57 \\
\hline
\end{tabular}

Using post-87 dummy variable

\begin{tabular}{lcccc}
\hline & \multicolumn{4}{c}{ Regression: } \\
\cline { 2 - 5 } Independent variable: & $(5)$ & $(6)$ & $(7)$ & $(8)$ \\
\hline Paper + CD flow & $1.39^{* * *}$ & $1.47^{* * *}$ & $1.64^{* * *}$ & $1.65^{* * *}$ \\
$\quad \times$ post-87 dummy & 0.50 & & & -0.05 \\
Bill flow & $-0.44^{* *}$ & $-0.55^{*}$ & $-0.42^{* *}$ & -0.46 \\
$\quad$ × post-87 dummy & & 0.22 & & 0.07 \\
Lagged Paper + CD share & $3.58^{* * *}$ & $3.73^{* * *}$ & $3.28^{* * *}$ & $3.29^{* * *}$ \\
$\quad$ post-87 dummy & & & $0.38^{* * *}$ & $0.38^{* * *}$ \\
P2-P1 spread & $0.60^{* * *}$ & $0.58^{* * *}$ & $0.65^{* * *}$ & $0.65^{* * *}$ \\
Constant & $-2.18^{* * *}$ & $-2.25^{* * *}$ & $-1.98^{* * *}$ & $-1.99^{* * *}$ \\
Trend & 0.0007 & 0.0007 & 0.0004 & -0.0006 \\
Test for excluding dummies & & & & $10.75^{* *}$ \\
\hline
\end{tabular}

Notes: Statistical significance is denoted by asterisks; $* * *$ for $1 \%,{ }^{* *}$ for $5 \%$, and $*$ for $10 \%$. The test for the joint exclusion of the dummy variables is asymptotically distributed as a $\chi^{2}$ with three degrees of freedom. See also notes to Table 2. 
decrease in the absolute value of any or all of these coefficients, but the respective t-statistics give no evidence of significant change after 1984 in any of them. The fourth column reports the results of allowing the coefficients on all three quantity variables to change simultaneously. Again none of the three t-statistics indicates significance of a shift at any reasonable level, and the $x^{2}$-statistic for the joint exclusion of all three shift terms is just 1.57 (not significant even at the 508 level).

The bottom panel of Table 3 reports equivalent results when the coefficients in equation (1) are allowed to shift beginning in 1987 , just at the beginning of the period of puzzling behavior of the paper-bill spread under scrutiny here. For this break point there is statistically significant evidence of a change in the coefficient on the lagged $(P+C D) /(P+C D+B)$ variable, but it is in the direction that increases the pre-1987 coefficient's absolute value. In short, these results provide no evidence whatever to support the suggestion that in recent years commercial paper and Treasury bills have become closer substitutes in investors' portfolios. 


\section{v. Conclusions and Implications}

The empirical work reported in this paper supports two different (but not mutually exclusive) explanations for the paper-bill spread's failure to anticipate the 1990-91 recession, but does not support a third explanation. There is evidence that the 1990-91 recession was unusual in not having been brought about by tight monetary policy, and that the paper-bill spread therefore did not anticipate the recession because at least part of the spread's systematic relationship to business cycle fluctuations reflects its role as an indicator of monetary policy. There is also evidence that movements of the spread during the several years prior to the 1990-91 recession were heavily influenced by changes in the outstanding quantities of commercial paper, bank CDs and Treasury bills that occurred for reasons unrelated to the business cycle. By contrast, there is no evidence that commercial paper and Treasury bills have become closer (perhaps even perfect) substitutes in recent years so that the spread between their respective interest rates is now mostly "noise" that would not be expected to exhibit systematic relationships to business cycle fluctuations.

The finding that asset quantity movements in particular heavily influenced the paper-bill spread during the period under study here highlights the burdens associated with the use of relative interest rate relationships as business cycle indicators. Standard portfolio theory shows that, in general, changes in asset quantities should affect interest rate spreads. The evidence assembled in this paper shows that, at least in the case of commercial paper and Treasury bills, changes in asset quantities do affect interest rate spreads. Some changes in asset quantities occur for reasons related to the business cycle (after all, that is what gives the spread its indicator properties in the first place) while others do not, but changes of both kinds affect the corresponding 
spreads. Naively using any particular interest rate spread as a business cycle indicator, without being sensitive to the possibility of idiosyncratic movements in the corresponding asset quantities and making due allowance for those movements when they occur, can therefore be a source of mistakes. 


\section{Footnotes}

*Harvard University and Federal Reserve Bank of Chicago, respectively. The authors are grateful to Joel Kreuger for research assistance; to Thomas Cosimano, John Golob, Paul Samuelson, Mark Watson and numerous other colleagues for helpful comments and discussions; and to the G.E. Foundation and the Harvard Program for Financial Research for research support. The opinions expressed here are the authors' own; they do not necessarily reflect official positions of the Federal Reserve System.

1. See, for example, Stock and Watson (1989), Bernanke (1990), Davis and Henry (1991), Friedman and Kuttner $(1992,1993$ a), Huh (1993), Ferderer et al. (1994), Lahiri and Wang (1994), and Miyao (1994).

2. The sample used here is 1959:1-1994:5. The data plotted in Figure 1 and cited here are for six-month maturities of both instruments. The empirical work presented throughout this paper relies on six-month maturities. Corresponding results based on three-month maturities (available from the authors on request) are highly similar.

3. See, in particular, Friedman and Kuttner (1993a) for an exploration of these hypotheses. For micro-level evidence on some of the same hypotheses, see Calomiris et al. (1994).

4. See, for example, Perry and Schultze (1993).

5. See, for example, Bernanke (1990), Friedman and Kuttner (1993a) and Kashyap et al. (1993).

6. Friedman and Kuttner (1993b) also offered a third potential explanation based on the difference in how "relationship" markets like the bank loan market and "arm's length" markets like the commercial paper market allocate the non-interest costs of borrowing.

7. The classic historical reference is Friedman and Schwartz (1963). Prominent examples of the more recent literature include Romer and Romer (1989) and Bernanke and Blinder (1992). For an opposing point of view, see, for example, Prescott (1986).

8. Cook (1981) was among the first to emphasize the imperfect substitutability of commercial paper and Treasury bills.

9. The empirical work presented in this paper follows the model in Friedman and Kuttner (1993b) in treating commercial paper and bank CDs as perfect substitutes in investors' portfolios. See the discussion below.

10. Kashyap et al. (1993) and Thoma and Gray (1994) have argued along these lines.

11. Between the inception of the system for rating commercial paper (after the 1970 Penn Central default) and yearend 1993, only seven rated issuers had defaulted, and five of these had lost their prime ratings before their 
defaults occurred. See Moody's Investors Service (1994) for a detailed history of experience under the rating system.

12. Bernanke (1990), Bernanke and Blinder (1992) and others have used the federal funds rate as a monetary policy indicator. See Sims (1992), however, for arugments against doing so.

13. Especially for recent years, it would also be plausible to include U.S. holdings of Eurodollar CDs and Eurodollar commercial paper as another close substitute for U.S. commercial paper. Since the mid 1980 s the spreads between interest rates on these instruments and paper rates in the United States have narrowed to levels indicating strong substitutability. Including these instruments in the ratio used for purposes of this paper's analysis makes little difference, however, both because outstanding Euro CDs and paper are still small compared to U.S. bills, paper and CDs, and because the movement in the volume of Euro CDs mirrored the decline in U.S. CDs beginning in 1989.

14. Data for CD's, taken from the Federal Reserve's break-down of M3, actually include all bank time deposits larger than $\$ 100,000$. Clearly, only those deposits that are in negotiable certificate form are close substitutes for commercial paper. This discrepancy is unlikely to present a serious problem for the analysis carried out here. Bank call report data indicate that CDs account for over $90 \%$ of all large time deposits, and the overwhelming majority of large certificates are known to be negotiable. (The Federal Reserve maintains no time series data that distinguish between certificates of deposit and other large time deposits, and no data at all distinguishing negotiable from non-negotiable certificates.)

15. The use of interest rate innovations as an indicator of monetary policy is subject to a familiar (but usually ignored) identification problem. Suppose, for example, that a sudden surge in consumer confidence leads to growth of aggregate demand sufficient to push the economy past full employment and thereby cause increased price inflation. If the central bank raises the federal funds rate in response to the resulting increased inflation and lower unemployment -. but does so only to the extent that it has historically varied the funds rate in response to similar macroeconomic conditions - - then the funds rate would exhibit no positive innovation in a system that included the appropriate macroeconomic variables. This problem is, in principle, subversive of any attempt to measure monetary policy by time series (for either interest rates or money growth) estimated as innovations in vector autoregression systems.

16. In contrast to the small effects of federal funds rate innovations shown in Figure 4 for the 1987-90 period, the identical exercise carried out for earlier years shows the effect on the paper-bill spread due to federal funds rate innovations varying from fust 5 basis points in September 1979 to 40 basis points the next month (after the initial adoption of new Federal Reserve operating procedures), on up to 51 basis points in March 1980, then down to -33 basis points in August 1980, then back up to 44 basis points in March 1981, and finally back to about zero that summer. These wide fluctuations are consistent with the usual interpretation of swings in monetary policy during this period. 
17. Some part of the decline in CDs outstanding was also due to the development, at about this time, of markets for medium-term notes issued by bank holding companies and "bank notes" issued directly by banks. The role of this innovation was small, however, compared to the decline of more than $\$ 100$ billion in outstanding CDs. As of yearend 1992, the total amount of medium-term notes outstanding was $\$ 17.9$ billion, and total gross issuance of underwritten bank notes during $1988-92$ was just $\$ 14.3$ billion. For a description of these markets, and data, see Crabbe (1993).

18. The data on the outstanding quantity of bills used in the empirical work presented below do not adjust for the effect of purchases by foreign central banks.

19. This equation follows those in Table 5.10 of Friedman and Kuttner (1993a).

20. To verify that the movements of the spread attributed here to changes in asset quantities are not just a consequence of "overfitting," equation (1) was re-estimated using data for the 1975-86 subsample only, and the resulting estimated equation used to project the paper-bill spread forward thereafter. A comparison of the estimated coefficients in this equation with those reported in Table 2, and of the corresponding projection results with those shown in Figure 7, shows that overfitting is not a problem here. The estimated coefficients on the quantity variables are at least as large as those in Table 2 , and the resulting projection is visually indistinguishable from that in Figure 7 . (The stability tests reported in Section IV below provide yet further reason to doubt that overfitting is a problem here.)

21. See again Kashyap et al. (1993) and Thoma and Gray (1994). 


\section{References}

Bernanke, Ben S. 1990. "On the Predictive Power of Interest Rates and Interest Rate Spreads." New England Economic Review (November/December), 51-68.

Bernanke, Ben S., and Blinder, Alan S. 1992. "The Federal Funds Rate and the Channels of Monetary Transmission." American Economic Review, 82 (September), 901-921.

Calomiris, Charles W., Himmelberg, Charles P., and Wachtel, Paul. 1994. "Commercial Paper and the Business Cycle: A Microeconomic Perspective." Mimeo: National Bureau of Economic Research.

Cook, Timothy. 1981. "Determinants of the Spread Between Treasury Bill and Private Sector Money Market Rates." Journal of Economics and Business, 33 (Spring), 177-187.

Crabbe, Leland. 1993. "Anatomy of the Medium-Term Note Market." Federal Reserve Bulletin, 79 (August), 751-768.

Davis, E.P., and Henry, S.G.B. 1991. "An Aggregate VAR Model with Financial Spreads." Mimeo: Bank of England.

Friedman, Benjamin M., and Kuttner, Kenneth N. 1992. "Money, Income, Prices, and Interest Rates." American Economic Review, 82 (June), 472-492.

Friedman, Benjamin M., and Kuttner, Kenneth N. 1993a. "Why Does the Paper-Bill Spread Predict Real Economic Activity?" Stock and Watson (eds.), Business Cycles, Indicators, and Eorecasting, Chicago: University of Chicago Press.

Friedman, Benjamin M., and Kuttner, Kenneth N. 1993b. "Economic Activity and the Short-Term Credit Markets: An Analysis of Prices and Quantities." Brookings Papers on Economic Activity (No.2), 193-283.

Friedman, Milton, and Schwartz, Anna J. 1963. A Yonetary History of the United States, 1867-1960. Princeton: Princeton University Press.

Huh, Chan. 1993. "Asymmetry in the Relationship Between Output and Interest Rates." Mimeo: Federal Reserve Bank of San Francisco.

Kashyap, Anil K., Stein, Jeremy C., and Wilcox, David W. 1993. "Monetary Policy and Credit Conditions: Evidence from the Composition of External Finance." American Economic Review, 83 (June), 78-98.

Lahiri, Kajal, and Wang, Jiazhuo G. 1994. "Interest Rate Spreads as Predictors of Business Cycles." Mimeo: State University of New York, Albany.

Miyao, Ryuzo. 1994. "Does a Long-run M2 Demand Relationship Really Exist in the United States? Evidence from Cointegration Tests." Essays in Money and Output. Ph.D. Dissertation, Harvard University. 
Moody's Investors Service. 1994. Commerclal Paper Defaults 1970-1993.

New York: Moody's Investor's Service.

Perry, George L., and Schultze, Charles L. 1993. "Was This Recession Different? Are They All Different?" Brookings Papers on Economic Activity (No.1), 145-211.

Prescott, Edward. 1986. "Theory Ahead of Business Cycle Measurement." Federal Reserve Bank of Minneapolis, Quarterly Review (Fall), 9-22.

Romer, Christina D., and Romer, David H. 1989. "Does Monetary Policy Matter? A New Test in the Spirit of Friedman and Schwartz." NBER Macroeconomics Annual, 121-169.

Sims, Christopher A. 1992. "Interpreting the Macroeconomic Time Series Facts: The Effects of Monetary Policy." European Economic Review, 36 (No.5), $975-1000$.

Stock, James, and Watson, Mark W. 1989. "New Indexes of Coincident and Leading Economic Indicators." NBER Macroeconomics Annual, 351-394.

Thoma, Mark A., and-Gray, JoAnna. 1994. "On Leading Indicators: Is There a Leading Contender?" Mimeo: University of Oregon. 